\title{
Psychodynamic Study on the Works of Cecelia Ahern
}

\section{OPEN ACCESS}

Manuscript ID:

ENG-2020-08033170

Volume: 8

Issue: 3

Month: June

Year: 2020

P-ISSN: 2320-2645

E-ISSN: 2582-3531

Received: 25.04 .2020

Accepted: 21.04.2020

Published: 02.06.2020

Citation:

MeenaKumari, V., and P. Shelonitta.

"Psychodynamic

Study on the Works of Cecelia Ahern." Shanlax International Journal of English, vol. 8, no. 3, 2020, pp. 60-64.

\section{DOI:}

https://doi.org/10.34293/ english.v8i3.3170

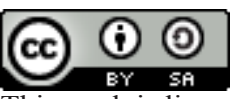

This work is licensed under a Creative Commons AttributionShareAlike 4.0 International License

\author{
V. MeenaKumari \\ Department of English, Anna Adarsh College for Women Chennai, Tamil Nadu, India \\ D https://orcid.org/0000-0001-9938-0135
}

\section{P. Shelonitta}

Anna Adarsh College for Women, Chennai, Tamil Nadu, India

\begin{abstract}
Sigmund Freud's psychoanalytical theory originally developed in the late 19th and early 20th centuries, in which Freud throws light into the "personality" of a human being. He gives a tripartite structure that involves a conscious (superego), pre-conscious (ego), and super-conscious (the 'id'). These concepts and their explanations form the fundamentals of the psychoanalytical theory. This thesis will focus on "Resistance and Repression," which is one among the many theories of psychoanalysis established by Freud. 'Repression' or also referred to as 'Suppression' by later psychologists, is the process of deliberately pushing out a painful thought, memory or feeling out of consciousness and becoming unaware of its existence, to which 'Resistance' acts as a safety measure by the mind in not giving entrance to certain painful memories into the conscious. This phenomenon plays a major role in the psyche of an average person as a "defense mechanism" to escape the anxiety that is caused by certain unacceptable concepts to the conscious mind. This thesis brings into light the psyche of the protagonist of Cecelia Ahern's novel "Postscript," who, throughout their life, represses painful events of the past, thus altering their decisions in life to a great extent. This work focuses on the behavioral patterns of the characters in the selected novels of study and the corresponding psychological traits that give an in-depth understanding of repression and its corresponding theories and their role in human life.
\end{abstract}

Keywords: Psychodynamics, Psychological, Repression, Resistance, Experiences, Fiction.

Fictional writers incorporate their inputs or experiences of their life into their works, making it more relatable for the reader for further interpretation. But every human being will not likely give away their entire story for others to read. Maybe it's a fear of giving in to vulnerability, or its just a way of living that we adapt to. The need to restrict from sharing one's feelings or emotions or even instances from one's own life is a form of resistance and repression - both of these referring to avoiding negative experiences and its corresponding feelings. One of the authors of the 21 st-century fiction, Cecelia Ahern waves the story of a young woman who undergoes bereavement after the loss of her partner in the first book and later in its sequel which had been released recently in 2019, transforms into a mature, understanding women with a broader perspective of looking for others instead of 'the self.'

Cecelia Ahern is a celebrated writer of Romance fiction. One of the powerful characters of Ahern is Holly Kennedy, the protagonist who appears in her works, 'PS I Love You' and 'Postscript' who experiences the death of her partner, followed by which her slow yet steady transformation leads her to a better person altogether. Though the transformation is steady, thoughts can always fluctuate between one side of the coin to another. These fluctuations are primarily caused by the discussed psychological phenomena, resistance, and repression. Before going into theory and analysis, it is necessary to understand 
the basis of human inter relation. Often deemphasized, it is an instinct of every human being to form a relationship with another. There are certain relationships that are designated from birth, and there are those that are created as time passes.

A sense of belonging to another, of creating relationships is a pleasurable and comforting phenomenon that every human being leans on. It is during the rattle of such relationships that certain instances of trauma affect the human brain. The death of a partner seems to statistically be on the top of situations in which the effect of trauma is the greatest. In Ahern's “P.S I Love You," Holly Kennedy appears at different stages of womanhood acting according to her age as life delivers new experiences each day. With the action commencing from the death of her husband, Gerry, at the cause of brain tumor, Ahern skilfully reports trances of Holly's memory into their past - of love and hope-giving the readers a deeper understanding of the relationship that they shared. Their love story began when they were too young such that they could associate only with each other. This association, a deep-rooted relationship, perhaps is why her husband, Gerry, plans to communicate with her for a whole year after his death through a set of letters that he writes for her. Those letters each have an activity, a challenge that Holly would have to fulfill for her dead husband, but more importantly for her, to get her moving amidst her grief. She finds herself getting motivated to do things that she wouldn't have done if not for her husband's letters. She finds herself a job that she finally loves going to and brings herself to a good place in life after having to spend most of her time with her ill husband for several months before his death. She had brought her life to a standstill when they discovered the illness, and she devoted most of her time caring for her husband and found every way to be with him throughout the day, making sure that she did not miss even a single second of his short time left. It's a story of love and loss, holding on and letting go, and, most importantly, learning to love again.

The novel "Postscript" is the following up of Holly's life after seven years of her partner's demise. The readers who are well acquainted with Holly's personality, now see a grown woman who has moved on, only until she's asked to give a podcast on her experience with Gerry's letters and how it had helped and transformed her to the woman she is today. A series of podcasts on "How to talk about..." was initiated by her sister, Ciara, in partnership with few charities as a way of indulging in a social cause. The podcast that Holly was a part of was an attempt to talk about 'death,' specifically grief and bereavement. It is this event that alters the future for Holly in a way she does not expect it to. Narration from Holly's perspective makes the novel all the more interesting with multiple interpretations.

"Shoot for the moon, and even if you miss, you'll land among the stars."

- Ahern (1)

In the prologue of the book, we see Holly revisiting this phrase that her husband Gerry often used, that it now memorably engraved on his tombstone. She recollects how she had felt in the days of her unbearable grief and how she had felt her husband's presence all the while either with or without her conscience.

She seems to understand that her husband had given her a second chance at a goodbye with the set of letters that he left for her. They shared two goodbyes, one with the terminal illness and another by his letters for about a year, which gives her more way to experience and intake the whole essence of her husband's departure but mostly the healthy and strong romantic relationship that they shared. The prologue, in itself a little disturbing, for it brings out the turbulences that are going to follow. She talks about the past from a far place of no effect but eventually confesses that at this point, seven years after his death, six years after she has read his final letter, recent events had unsettled everything and rattled her core. She feels the need to move forward, but feels a hypnotic rhythmic tide, as though his hand is reaching her and pulling her back. Although there is this urge to let go, to understand that it is necessary to move on with life, there is a concurring fluctuation.

Holly, too, had undergone a period for mourning her loss. Morning according to Freud refers to the "effect of grief and its outward manifestation." In experiences that circle grief, resistance and repression are the immediate response; phenomena that can be referred to not just the thoughts that arise in one's mind, but in equal consideration for feelings 
that arise with those specific thoughts. In this novel, Holly shows resistance when it comes to taking new turns in her life, like moving in with her current boyfriend and to get the guts to speak on her sister's podcast. In the first scenario, she cannot let go of the house that she and Gerry had lived in, that activates great resistance with or without her knowing it, towards moving on. However, it had been her choice and was not forced into a decision.

Here, the house has memories of not just herself but of Gerry. She recollects their idea of getting a 'starter home' and moving on to a better one once the finances are good, her marital outset, and even their minute memories that exist with the house. Her resistance to give it up is the fear of not having sensual reverberations of her past. We find out through her sister Ciara's introduction of Holly that she had been resistant for about a year to participate in the podcast that her sister had been persuading her to, which reflects her thought process on the growth that she has attained from the time of her husband's death and reflects on the consequences that she might have to face if she lets herself slip and fall back reliving the grieving days after Gerry's death.

She talks about her altered state of mind about the events that have followed up after the podcast. Her eventual agreement on giving the podcast was generated by considering Ciara's persistence and the fact that it was a one-time thing, and it would not reappear once it's done and dusted. But she eventually gets to know that her podcast had gone viral and there is a group of people who name themselves (after the famous phrase Gerry wrote at the end of each letter, PS, I love you) the PS I love you club. They approach Holly at Ciara's antique shop and request her to help them achieve the same that her husband had for their loved ones. They want to write letters or leave videos that would be a reminder of them after they've gone. This group of people also suffer from a terminal illness, or a life-long condition or are in remission of the same, resembling Gerry a little. Initially, with this group, she shows high levels of disinterest that she avoids even talking to people who seem likely to approach her about the podcast. She had been asked for some kind of help, and her need to at least get them their reply of refusal she calls one of their houses only to know that the person who has approached her to talk about her podcast had died of cancer. Her steaming guilt leads her to visit the funeral only to know that the dead person had used Gerry's idea to leave something behind. She leaves videos to be played at the funeral. After talking to some of them and realizing the creation of a club of 5 people who seek help in following Gerry's path.

It is through this journey of deciding whether to help these people or not that she goes into her first phases of repression, her dilemma of whether to involve herself to withdraw. She accepts to attend a meeting in which all of them convey their ideas, some stick to letters, some to videos, quizzes, etc. Her conscious effort is to be gone before she got too involved.

It is important to note that though this kind of repression is not of the unconscious mind, it can also be referred to as suppression. Psychoanalysts and psychology scholars had stated that Freud had perhaps indicated the mechanism of suppression when he had used the term repression by giving two alternative definitions that refer both to the working of the unconscious as well as the conscious mind. With this difference in thought, to continue this thesis on one aspect of this suppression/repression that occurs consciously where the person wants to avoid thoughts that might distress his/her mind. When taking the term suppression to analyze the following three mind-sets of Holly, we need to remember that the consequence of suppression is that the conscious effort to push away the unwanted thought only makes it impossible to disappear. It thereby takes a stand and settles its way into your consciousness despite that being the exact opposite of your aim. There are many instances in the novel that the character shows heavy signs of repression and resistance against moving on,

This one page in the entire novel portrays another face of the two-dimensional woman that Holly carries with her. The one that accepts the loss and there is another soft, fragile woman who has experienced loss in its complexity and is living a life she would not have imagined living. At the peck of a troublesome situation, this woman comes to the surface bringing with herself all the fragile emotions that the trauma had once unraveled. This, again, is an effect of suppression. 
With these incidents that torment her internally, letting her heart go soft and hurt, she has a definite perception of what problems are and how one has to act. Her perception of these hard situations does not seem to alter the fact that she still can be emotionally unstable at the stroke of a minute reminder but enhances her growth by distributing energy to the positive perspective instead of the negative. There is a deeper sense of withdrawal from reality, from what had happened and how she is feeling deep down. This happens when a person strives to let go of what has affected them by putting themselves in a comfortable, more optimistic place in the matter of thoughts, people, and places. It is a mere survival instinct that is applied as one knows that loss cannot object and stop the lives of others even though it seems to be. A person who has lost a partner at a young age experiences bereavement, depending on his/her resilience rate coping occurs. The rate of the loneliness and suffering that he/she experiences is unequaled with any other kind of loss.

Overcoming this sense of loss is what triggers resistance and repression such that the person expresses negligence or declination for quite a period until it backfires. Still, this phenomena's application often seems to collapse, because something as important as recognizing and grieving for a loss cannot be side-tracked. A mere resemblance of something similar to Holly's husband, his disease, literally anything that she could relate to him would create a moment of despair. Psychologists assure that the side effect of this immense wants to control their mind only leads it more astray.

\section{References}

Abram, Jan. The Language of Winnicott: A Dictionary of Winnicott's Use of Words. Karnac Books, London, 1996.

Ahern, Cecelia. Please I love you. Granth, 2011.

Ahern, Cecelia. Postscript. Harper Collins, 2019.

Bauer, Gregory P. Wit and Wisdom in Dynamic Psychotherapy. Jason Aronson, 1990.

Cabaniss, Deborah L. et al. Psychodynamic Psychotherapy. Wiley, 2010.

Chalquist, Craig, and Mary E Gomes. Terrapsychology: Re-engaging the Soul of Place / Craig Chalquist. Spring Journal Books, 2007.
Chessick, Richard.ADictionaryfor Psychotherapists: Dynamic Concepts in Psychotherapy. Jason Aronson, 1993.

Chetwynd, Tom. Dictionary for Dreamers. Granada, London, 1972.

Chetwynd, Tom. Dictionary of Symbols. Granada Paperback, London, 1982.

Cortina, Mauricio. "The Future of Psychodynamic Psychotherapy". Psychiatry: Interpersonal And Biological Processes, vol. 73, no. 1, 2010, pp. 43-56.

Drever, James. A Dictionary of Psychology. Penguin Books, 1952.

Feltham, Colin and Dryden, Windy. Dictionary of Counselling. Whurr Publishers, London, 1993.

Freud, Sigmund, and Brill, A. A. The Basic Writings of Sigmund Freud. Modern Library, 1995.

Gabbard, Glen O. Long-Term Psychodynamic Psychotherapy: A Basic Text. American Psychiatric Publishing, Inc., 2010.

Gabbard, Glen O. Psychodynamic Psychiatry In Clinical Practice. American Psychiatric Publishers, 2014.

Hinshelwood, R. D. A Dictionary of Kleinian Thought. Free Association Book, London, 1989.

Hoffer, Axel. Freud And The Buddha: The Couch and the Cushion. Karnac Books, 2015.

Jacobs, Michael. Sigmund Freud. SAGE, 2003.

Kovel, Joel. A Complete Guide to Therapy: From Psychoanalysis to Behaviour Modification. Penguin Books Ltd, 1978.

Laplanche, Jean, and J.-B Pontalis. The Language of Psycho-Analysis. Hogarth Press, 1973.

Laplanche, Jean and Pontalis, Jean-Bertrand. The Language of Psycho-Analysis. The Hogarth Press and the Institute of Psycho-Analysis, London, 1973.

McLeod, John. Doing Counselling Research. Sage Publications, 2003.

Moore, Burness E. and Bernard D. Fine. Psychoanalytic Terms \& Concepts. The American Psychoanalytic Association and Yale University Press, 1990. 
Racker, Heinrich. Transference And CounterTransference. American Psychoanalytic Association, 2008.

Shedler, Jonathan. "The Efficacy of Psychodynamic Psychotherapy." American Psychological Association, vol. 65, no. 2, 2010, pp. 98-109.
Smith, Vicki et al. Key Concepts in Counselling and Psychotherapy. Mcgraw-Hill Education, 2012.

Wilson, Stephen, and Oscar Zarate. Introducing The Freud Wars. Icon, 2012.

\section{Author Details \\ Dr. V. MeenaKumari, Department of English, Anna Adarsh College for Women, University of Madras, Chennai, Tamil Nadu, India.}

P. Shelonitta, Anna Adarsh College for Women, Chennai, Tamil Nadu, India. Email ID: shelonitta1697@icloud.com. 